\title{
State of the Art and Future Prospects of Alternative Control Means Against Postharvest Blue Mould of Apple: Exploiting the Induction of Resistance
}

\author{
Simona Marianna Sanzani and Antonio Ippolito \\ Department of Environmental and Agro-Forestry Biology and Chemistry, \\ University of Bari "Aldo Moro"
}

Italy

\section{Introduction}

Fresh fruit and vegetables supply essential nutrients, such as vitamins and minerals, and are a major source of complex carbohydrates, antioxidants, and anticarcinogenic substances which are important to human health and well being (Arul, 1994). Being aware of the advantages potentially coming from their use, the consumers' demand for fresh products has greatly increased during recent years. On the other end, the possible presence of chemical residues, mycotoxins and other contaminants of fruit and vegetables (Paster et al., 1995), creates great concern among consumers for safety issues.

Therefore, aim of an adequate storage is to help the harvested fruit and vegetables to arrive at their destination fresh, disease-free, and safe for consumers, despite the complexity of treatments they have to undergo prior to or during storage, and the long period between harvest and consumption. All the means and methods with the power to aid in preserving the quality of the harvested products and in protecting them from decay agents during storage and shelf-life, are aimed at this objective.

\section{Apple: Origin, distribution and economic importance}

Apples (Malus domestica Borkh.) belongs to the Pomoideae subfamily Rosaceae, along with pear (Pyrus communis L.), apricot (Prunus armeniaca L.), prune (Prunus domesticus L.), cherry (Prunus avium L.) and peach (Prunus persica L.). Actually there is a debate about whether M. domestica originated from hybridization among various wild species or from a single species, still growing on the Northern slopes of the Tien Shan mountains at the border between northwest China and the former Soviet Republic of Kazakhstan (Phipps et al., 1990; Juniper \& Mabberley, 2006). Apples were consumed by human beings since the Stone Age, as documented by numerous Neolithic finds discovered in Northern Europe. In the medieval times monasteries were responsible for selection, propagation, and perpetuation of hundred of different cultivar types. In the Nineteenth Century these types became the ideal stock for horticulturists to develop techniques to cross desirable selections. From that time M. domestica cultivars spread 
throughout the world, particularly in North America, Russia, Australia, and Japan. Over 7500 apple cultivars are known, but even though nowadays breeders worldwide create new selections annually, only very few of them are widely produced (Janick, 1996).

In 2008 apple constituted the third fruit most cultivated in the world with and area of 4,696,472 hectares and a production of 69,304,442 tonnes (Food and Agriculture Organization of the United Nations [FAO], 2011). Moreover, Italy represented in the world the sixth highest producing country (more than 2 million tonnes), and the first exporting one (683 thousand tonnes); whereas, apple consumption was estimated to be $47.78 \mathrm{~g} /$ day/capita (FAO, 2011). The apple production is concentrated in Northern Italy: $80 \%$ of the crop, in fact, comes from Trentino-Alto Adige (46\%), Emilia-Romagna (17\%), and Veneto (14\%) regions. Golden Delicious and Granny Smith are two of the most popular apple cultivars among consumers. In Italy apples are mainly consumed as fresh commodity, whereas in Northern Europe and America they are used for juices and cider production.

Apples are commonly harvested from the end of August till mid-October, although, because of the postharvest practices (pre-refrigeration, controlled atmosphere, etc.), they can be stored for long times and so are available on commerce all through the year.

\section{Apple pathogens and diseases}

The surface of fruit or vegetables is covered by fungal and bacterial propagules that they have acquired from the air during their development on the parent plant, or with which they have come in contact during picking or any of the subsequent stages of handling. However, most fungal and bacterial propagules that reach the harvested product do not cause decay, even when conditions suitable for penetration and development are present.

Harvested fruit and vegetables are naturally attacked by a relatively small group of pathogens: approximately forty species. However, each fruit or vegetable has its own typical pathogens out of this particular group. Eckert \& Ogawa (1988) divided the major postharvest pathogens of pome fruits into two groups: (a) those that cause quiescent infections of lenticels, including Phlyctema vagabunda Desm. (syn. Gloeosporium album), G. perennans Zeller \& Childs (syn. Cryptosporiopsis curvispora) and Nectria galligena Bresad; and (b) those that preferably enter through wounds after harvest, including Penicillium expansum Link, Botrytis cinerea Pers. ex Fr., Monilinia spp., Mucor spp., Rhizopus spp., Alternaria alternata (Fr.) Keissl, Stemphylium botryosum Wallr, and Cladosporium herbarum (Pers.) Link. The rots in the lenticels are initiated in the orchard in the late summer, and are a major problem for apples grown in areas with late summer rainfall such as the United Kingdom and Northern European Countries (Edney, 1983). In drier apple production areas, main problems are caused by wound pathogens that invade the fruit after harvest through injuries sustained during harvesting and handling and via puncture wounds, bruised lenticels, etc. Other important pathogens of pome fruits are species of Phytophthora, that may become a serious problem during rainy seasons for fruit from orchards with heavy soils (Edney, 1978), and Colletotrichum gloeosporioides Penz (syn. Gloeosporium fructigenum), the bitter rot fungus, which is capable of direct penetration of the intact skin (Brook, 1977). Botryosphaeria spp., the black and white rot fungi, are of importance in several areas of the USA (Snowdon, 1990). Finally, pathogens of minor importance that may occasionally be found on harvested apples and pears include Trichothecium roseum Link, and species of Phomopsis, Nigrospora, Fusarium, Epicoccum, Aspergillus, and Trichoderma (Snowdon, 1990). 


\subsection{Penicillium expansum}

The blue mould rot, caused by P. expansum, is one of the most common and destructive rots of harvested apples and pears, but it can also be found on sweet cherries and other commodities such as apricots, grapes, blueberries, peaches, strawberries, walnuts, pecans, hazelnuts, and acorns (Andersen et al., 2004; Murphy et al., 2006). Blue mould is a worldwide severe disease, even in production areas where the most advanced storage technologies are available. In Northern Europe the estimated incidence of this disease varies between seasons and cultivars, ranging from 5 to 20\% (Mari et al., 2002). P. expansum is primarily a necrotroph and a wound parasite, most frequently gaining entrance through fresh mechanical injuries such as stem punctures, bruises and insect injuries, finger-nail scratches by pickers and necrotic tissues of diverse origin, for instance due to infections by other pathogens, such as Gloeosporium spp., Phytophthora spp., and Mucor spp. (Snowdon, 1990). Thus, resistance of the epidermis to breakage may be an important factor in the resistance of apple cultivars to decay. Studying the force required to break the epidermis of several cultivars, as a criterion for resistance to wound pathogens, Spotts et al. (1999) found that the epidermis of Golden Delicious and Jonagold was more easily broken than that of other cultivars, while the epidermal tissues of Fuji and Granny Smith were the most resistant to puncture. Sometimes infections may occur through normal stems, open calyx canals or lenticels, especially when they are damaged by cracking after a sudden abundant supply of water following a period of dryness, or after bruising late in the storage season when fruit have been weakened by ripening and aging (Janisiewicz et al., 1991).

The fungus produces pale brown to brown soft-watery spots that enlarge rapidly under shelf life conditions. Under humid conditions, conidia-bearing conidiophores group to form coremia on the surface of the lesion. As the conidia mature, they turned from nearly snow white to blue-green and form masses which give the decay its typical colour. Another characteristics, important in the recognition of P. expansum, is the earthy, musty odour.

Since decay development is favoured by high humidity, the blue mould is a particularly serious problem on fruits stored or shipped in plastic film liners (Hall \& Scott, 1989). Decay can progress, albeit slowly, during cold storage; rapid development begins when the fruits are transferred to warmer conditions. The fungus can spread during the postharvest handling, since the blue mold spores are long-lived and may easily survive from season to season on contaminated bins, where the fungus can grow and produce copious amounts of spores. Contamination with these spores may come from various other sources including orchard soil present on bins, decaying fruit or air. Inoculation of the fruit going into storage is believed to occur mainly from the diphenylamine (DPA) drenching solution used for protection against superficial scald, where the spore concentration increases with each successively drenched bin and may reach high levels if solutions are not changed regularly. Inoculation can also occur during fruit handling in water contaminated with the fungus in packing houses. A single decayed fruit may contain enough spores to contaminate water of the entire packing line (Janisiewicz et al., 1991). At present few chemicals are permitted in Europe to be used in the postharvest phase: for instance, only thiabendazole and pyrimethanilare are allowed in Italy for postharvest control of blue mold. Moreover, during the past few decades thiabendazole has lost efficacy due to the establishment of resistant pathogen populations (Baraldi et al., 2003).

Finally, it should be considered that contamination of fruits by P. expansum not only results in economic losses during storage and shelf-life, but it also has a potential public health significance, since some strains of $P$. expansum produces the mycotoxin patulin. 


\subsection{Patulin}

Thousands of mycotoxins exist, but only a few represent significant food safety challenges. The most important mycotoxins impacting food production and manufacturing are: patulin, produced by Penicillium species (mainly from P. expansum); ochratoxin, which is present in a large variety of foods as it is produced by several fungal strains of Penicillium and Aspergillus species; zearalenone, found prevalently in grains infected by Fusarium graminearum Rank; aflatoxins, mainly produced by Aspergillus flavus Link and A. parasiticus Speare; trichothecene, whose production is known for several Fusarium species; and, finally, fumonisins mainly produced by the maize pathogens Fusarium verticillioides (formerly F. moniliforme) (Sacc.) Nirenberg and F. proliferatum (Matsush.) Nirenberg ex Gerlach and Nirenberg.

Of special interest to postharvest pathology is the production of patulin by $P$. expansum in pome fruits. Patulin $\{4$-hydroxy- $4 \mathrm{H}$-furo[3,2-c]pyran-2(6H)-one $\}$ is a polar compound transferred in fruit juices if rotten fruits, especially apples, are not picked up during fruit juice processing. There is no clear evidence that patulin is carcinogenic, however, it has been shown to cause immunotoxic effects (Pacoud et al., 1990) and to be neurotoxic in animals (Deveraj et al., 1982), so that the European Commission in 2006 established the maximum levels of patulin permitted in foodstuffs (European Commission, 2006). The amount of patulin produced by $P$. expansum may vary greatly according to the strain involved. Sommer et al. (1974) found that patulin production in different strains of $P$. expansum in Golden Delicious apples ranged from 2 to $100 \mu \mathrm{g}$ gram $^{-1}$ of tissue. On the other hand, other constitutive and environmental parameters, such as the cultivar and the storage temperature may influence patulin accumulation. Paster et al. (1995) demonstrated that while more patulin was produced in Starking apples than in Spadona pears held at $0-17^{\circ} \mathrm{C}$, higher toxin levels were produced in pears than in apples held at $25^{\circ} \mathrm{C}$. Furthermore, a consistent reduction in patulin production was observed when inoculated apples were held in a $3 \% \mathrm{CO}_{2} / 2 \% \mathrm{O}_{2}$ atmosphere. Thus, it can be concluded that the ability to produce patulin and the amounts of patulin produced depend on fungal strain, fruit cultivar, storage temperature, and composition of storage atmosphere (Lovett et al., 1975; Paster et al., 1995). Finally, it has to be considered that, patulin, as many fungal secondary metabolites, has an antibiotic activity. This ability is particularly useful because the secondary products may represent competitive weapons in nature (Sutton, 1996).

\section{Alternative control means}

The development of resistance, together with the increasing concern about possible adverse effects on human health and environment caused by fungicides, have contributed to arouse interest in the development of alternative means for controlling plant pathogens, capable of integrating, if not totally replacing, synthetic fungicides. Substantial progress has been made in finding alternatives to synthetic fungicides for the control of postharvest diseases of fruit and vegetables (Ippolito et al., 2004; Palou et al., 2008; Sanzani et al., 2009a; Schena et al., 2007; Sharma et al., 2009; Zhang et al., 2009).

Emerging postharvest biocontrol technology employs different approaches, such as use of physical means, natural biocides, antagonistic microorganisms and their products, or the intensification of natural defense mechanisms. Treatments that have been evaluated for effectiveness against $P$. expansum on apples include chlorine dioxide administration in aqueous environment (Okull et al., 2006); surface application of cinnamon oil or potassium sorbate (Ryu 
\& Holt, 1993); fumigation with acetic acid vapor (Sholberg et al., 2000); immersion in electrolyzed oxidizing water (Okull \& LaBorde, 2004). A wash treatment with $\geq 2 \%$ acetic acid for more than $1 \mathrm{~min}$ proved to be effective in completely inhibiting $P$. expansum growth and relevant patulin production on apples destined for cider (Chen et al., 2004). Hot water immersion inhibited decay development in P. expansum-inoculated apples (Fallik, 2010).

Several examples of success in preventing $P$. expansum rots during postharvest phase of fruits by using yeasts antagonists (Ippolito et al., 2000; Zhang et al., 2009), bacteria (Morales et al., 2008) and biologically active natural products (Mari et al., 2002), have been reported. The antifungal effectiveness of an antagonist can be increased by addition of substances, as in the case of sodium bicarbonate in combination with a strain of Metschnikowia pulcherrima (Spadaro et al., 2004). Finally the controlled atmosphere (CA), used for the long-term storage of apples, may also influence the efficacy of biocontrol agents by affecting their vitality or by altering the physiological status of the treated fruits (Chalutz \& Droby, 1997).

\subsection{Host protection and defence mechanisms}

Induced disease resistance has been adopted as a general term and defined as the process of active resistance, dependent on the physical or chemical barriers of the host plant, activated by biotic or abiotic agents (inducing agents)' (Kloepper et al., 1992). In compatible plantfungus interactions resistance mechanisms may be activated too slowly to be effective or be suppressed by the invading pathogen. So the level of basic resistance may simply not be sufficient to halt infection and prevent extensive tissue colonization and symptom development. Whereas, in induced tissues the balance may be shifted in favour of the plant, by an earlier and quicker response, that can be effective in limiting tissue colonization to various extents, depending on the specific plant-pathogen relationship.

Plants respond to invasion by pathogens with an array of biochemical and genetic changes, including the production of reactive oxygen species (ROS), antimicrobial compounds, antioxidants, and signalling molecules such as salicylic acid (SA), ethylene and jasmonic acid (JA) (Mahalingam et al., 2003). They also respond by the localized activation of a celldeath program, designated "hypersensitive response (HR)", and by the systemic activation of cellular and molecular defences, termed "systemic acquired resistance (SAR)" (Ryals et al., 1996). There is evidence for commonalities between plant responses to pathogens (referred to as defence responses) and environmental stresses (referred to as stress responses). However, a plant response to each environmental challenge is unique and tailored to increasing the plant ability to survive the inciting stress.

Most plant antimicrobial natural products have relatively broad spectrum activity, and specificity is often determined by whether or not a pathogen has the enzymatic machinery to detoxify a particular host product. Accumulation of inducible antimicrobial compounds is often orchestrated through signal-transduction pathways linked to perception of the pathogen by host receptors. The simplest functional definitions recognize phytoalexins as compounds that are synthesized de novo and phytoanticipins as pre-formed infectional inhibitors. However, the distinction between phytoalexin and phytoanticipin is not always obvious, as some compounds may be phytoalexins in one species and phytoanticipins in others (Dixon, 2001).

Phytoalexins are low-molecular-weight toxic compounds mainly produced in the host tissue in response to initial infection by microorganisms (Harborne, 1999). In other words, in order 
to overcome an attack by the pathogen, the host is induced to produce antifungal compounds that would prevent pathogen development. However, the accumulation of phytoalexins does not depend on infection only. Such compounds may be elicited by microbial metabolites, mechanical damage, plant constituents released after injury, a wide diversity of chemical compounds, or by low temperature, irradiation, and other stress conditions. Phytoalexins are, thus, considered to be general stress-response compounds, produced after biotic or abiotic stress. The most available evidence on the role of phytoalexins shows that disruption of cell membranes is a central factor in their toxicity (Smith, 1996), and that the mechanism is consistent with the lipophilic properties of most phytoalexins (Arnoldi \& Merlini, 1990).

Earlier studies by Müller \& Borger (1940) already provided strong evidence that resistance of potato to Phytophthora infestans (Mont.) de Bary is based on the production of fungitoxic compounds by the host. A terpenoid compound, rishitin, produced in potato tubers following infection by $P$. infestans, was first isolated by Tomiyama et al. (1968) from resistant potatoes inoculated with the fungus. It accumulates rapidly in the tuber and reaches levels much higher than those required to prevent fungal development. The relationship between the accumulation of rishitin in the tuber and its resistance to late blight may point to its role in resistance development (Kuc, 1976). Other sesquiterpenoids that have been found in potatoes may also play a role in tuber disease resistance; they include rishitinol (Katsui et al., 1972), lubimin (Katsui et al., 1974), oxylubimin (Katsui et al., 1974), solavetivone (Coxon et al., 1974), and others. These sesquiterpenoids proved also to be effective in suppressing mycelial growth of the potato pathogen $P$. infestans on a defined medium (Engstrom et al., 1999). Moreover, several phytoalexins, such as umbelliferone, scopoletin, and esculetin, are produced in sweet potato roots infected by the fungus Ceratocystis fimbriata Ellis and Halsted; it was noted that these compounds accumulate more rapidly in roots resistant to this fungus than in sensitive roots (Minamikawa et al., 1963).

Further studies with celery (Afek et al., 1995a) indicate that (+) marmesin, the precursor of linear furanocoumarins in this crop, is the major compound involved in celery resistance to pathogens, indeed increased susceptibility of stored celery to pathogens is accompanied by a decrease in $(+)$ marmesin concentration. Indeed treatment of celery prior to storage with gibberellic acid (GA3), a naturally occurring phytohormone in juvenile plant tissue, resulted in decay suppression during 1 month of storage at $2^{\circ} \mathrm{C}$, although GA3 does not have any effect on fungal growth in vitro (Barkai-Golan \& Aharoni, 1976). It was suggested that the phytohormone retards celery decay during storage by slowing down the conversion of $(+)$ marmesin to psoralens, thereby maintaining high level of $(+)$ marmesin and low levels of psoralens and, thus increasing celery resistance to storage pathogens (Afek et al., 1995b). Another phytoalexin found in celery tissue is columbianetin, which probably also plays a more important role than psoralens in celery resistance to decay (Afek et al., 1995c). This hypothesis is derived from the following facts: (a) columbianetin exhibits strong activity against $A$. alternata, B. cinerea, and Sclerotinia sclerotiorum (Lib.) de Bary, the main postharvest pathogens of celery; (b) the concentration of columbianetin in the tissue is close to that required for their suppression; (c) increased sensitivity of celery to pathogens during storage occurred in parallel with the decrease in the concentration of columbianetin.

The phytoalexin capsidiol is a sesquiterpenoid compound produced by pepper fruits in response to infection by a range of fungi (Stoessl et al., 1972). Pepper fruits inoculated with 
B. cinerea and Phytophthora capsici Leon contain only small quantities of capsidiol, whereas fruits inoculated with saprophytic species or with weak pathogens may produce higher concentrations of the phytoalexin, which inhibit spore germination and mycelial growth. Inoculating peppers with Fusarium species results in increased capsidiol concentration from 6 to $12 \mathrm{~h}$ after inoculation. In such cases, the capsidiol accumulation in the tissue is rapid, whereas in other cases it is quickly oxidized to capsenone, which is characterized by a much weaker toxic effect. When unripe pepper fruits were inoculated with Glomerella cingulata Stonem, the causal agent of anthracnose, a phytoalexin was readily identified in tissue extracts (Adikaram et al., 1982). This compound, possibly related to capsidiol but much less water soluble, has been named capsicannol (Swinburne, 1983).

The resistance of unripe banana to anthracnose incited by Colletotrichum musae Berk and Curt has been attributed to the accumulation of five fungitoxic phytoalexin compounds that were not present in healthy tissue. As the fruit ripened these compounds diminished and, at a progressive stage of disease development, no phytoalexins were detected (Brown \& Swinburne, 1980). Elicitors composed of a glucan-like fraction of the cell walls of hyphae and conidia of C. musae elicited both necrosis and the accumulation of the two major phytoalexins found in naturally infected tissues.

The apple main phytoalexins are phloretin, naringenin, quercetin, $(+)$-catechin and benzoic acid (Burse et al., 2004; Gottstein et al., 1992; Iwashina, 2003). Benzoic acid is produced in apples as a result of infection by Nectria galligena and other pathogens. Fruit resistance to this pathogen at the beginning of a long storage period was attributed to the formation of this phytoalexin (Swinburne, 1973). Nectria penetrates apples via wounds or lenticels prior to picking, but its development in the fruit is very limited. Benzoic acid is the compound isolated from the limited infected area. The elicitor of benzoic acid synthesis was found to be a protease produced by the pathogen (Swinburne, 1975). This protease is a non-specific elicitor and a number of proteases from several sources may elicit the same response. On the other hand, P. expansum, B. cinerea, Sclerotinia fructigena Pers., and Aspergillus niger van Tieghem, which do not produce protease in the infected tissue and do not induce the accumulation of benzoic acid, can rot immature fruit (Swinburne, 1975).

The in vivo levels of the principal phenolic compounds found in olive plants infected by Phytophthora megasperma Drechsler and Cylindrocarpon destructans (Zinssm.) Scholten differed from the levels observed in non-infected plants. When the antifungal activity of these compounds against both fungi was studied in vitro, the most active were quercetin and luteolin aglycons, followed by rutin, oleuropein, $p$-coumaric acid, luteolin-7-glucoside, tyrosol, and catechin (Baidez et al., 2006). Moreover, it has been reported that the antifungal activity of aqueous neem leaf extract against $P$. expansum was related to the presence of highly bioactive compounds including quercetin (Allameh et al., 2001; Mossini et al., 2004).

Inoculating citrus fruits with their specific pathogens Penicillium digitatum Pers. and Penicillium italicum Wehm results in the accumulation of the phytoalexins scopoletin, scoparone, and umbelliferone. The induced compounds have a greater toxic effect than that of the preformed antifungal compounds naturally found in the fruit tissue, such as citral and limetin, as indicated by the inhibition of $P$. digitatum spore germination (Ben-Yehoshua et al., 1992). The antifungal activity of both scoparone and scopoletin against and $P$. digitatum was observed in UV-C irradiated grapefruits (D'hallewin et al., 2000; Rodov et al., 1992). Indeed, a correlation has been drawn between the level of phytoalexin accumulated in the flavedo of 
irradiated fruits and its increased resistance. In particular, decay reduction was achieved when irradiation was applied to the fruit prior to its inoculation, and therefore without any direct exposure of the pathogen to the radiation; this finding led to speculate that disease inhibition stems from increased resistance of the fruit to infection and not from the direct fungicidal effect of UV on the pathogen (Rodov et al., 1992). Moreover, Kim et al. (1991) reported that the increased concentration of scoparone in heat-treated lemon fruits was in good correlation with their increasing resistance to $P$. digitatum and enhanced antifungal activity of the fruits extract. Similarly, Afek et al. (1999) reported that umbelliferone accumulated in the albedo of pathogen-challenged grapefruit played a role in defence mechanisms of immature grapefruit against wound pathogens such as P. digitatum.

Biosynthesis of toxic compounds as a result of wounding or other stress conditions, is a ubiquitous phenomenon in various plant tissues. An example of such a synthesis is the production of the toxic compound 6-methoxymellein in carrot roots in response to wounding or to ethylene application (Chalutz et al., 1969; Coxon et al., 1973); the application of $B$. cinerea conidia and other fungal spores to the wounded area was found to stimulate the formation of this compound (Coxon et al., 1973). This 6-methoxymellein probably has an important role in the resistance of fresh carrots to infection. Carrots that have been stored for a long period at a low temperature lose the ability to produce this compound and, in parallel, their susceptibility to pathogens increases.

Resveratrol is a phenolic substance present in both grape skin and wines in response to various fungal infections, UV radiation, or chemicals (Adrian et al., 1997; Jeandet et al., 1995; Langcake, 1981) and it is involved in grey mould resistance (Celotti et al., 1996; Gonzalez Ureña et al., 2003).

The garlic and strawberry phytoalexin esculetin showed a strong activity against fungal strains, especially Trichophyton mentagrophytes Malmsten and Rhizoctonia solani J.G. Kühn (Cespedes et al., 2006), whereas a moderate antifungal activity against Fusarium spp. was reported for ferulic acid (Walker et al., 2003).

\subsection{A case study: The flavonoid quercetin}

Enhanced protection of host plant tissue during periods of susceptibility through induced/acquired resistance is considered a preferred strategy for achieving integrated pest management (Kuć, 2000). Luckey (1980) reported that natural disease resistance may be induced by low or sub-lethal doses of an elicitor/agent, such as a chemical inducer or a physical stress. For instance, chemical activators could act by modifying the plant-pathogen interaction so that it resembles an incompatible interaction with defence-related mechanisms induced prior to or after challenge (Sticher et al., 1997).

Flavonoids is the general name of compounds that have a fifteen-carbon skeleton, which consists of two phenyl rings connected by a three-carbon bridge. They are potent dietary antioxidants that are found in several plant materials. They are also thought to improve human health and this effect seems related, at least partially, to their antioxidant effect (Nijveldt et al., 2001). Ingham et al. (1972) have reviewed the role of flavonoid phytoalexins and other natural products as factors in plant disease resistance. Among these compounds, quercetin was considered the most prominent (Bock, 2003). It consists of 3 rings and 5 hydroxyl groups and occurs in food (i.e. apple, tea, onion, nuts, berries, cauliflower and 
cabbage) as the aglycone (attached to a sugar molecule) of many plant glycosides. Quercetin can scavenge superoxide and hydroxyl radicals and reduce lipid peroxidation. In addition, it has been reported that quercetin reduces the biosynthesis of heat shock proteins, by reducing the heat shock factor which is the transcriptional factor contributing to their expression (Ishida et al., 2005). However, nothing is known about its possible mode of action in reducing blue mould incidence and severity in apple fruit.

In recent publications the flavonoid quercetin, commonly available on commerce, even as dietary supplements, was tested both in vitro and in vivo against blue mould and relevant patulin accumulation on apples (Sanzani et al., 2009b). The in vitro trials on amended and non-amended PDA plates revealed that although quercetin, at the tested concentrations (100 $\mu \mathrm{g} /$ dish), exerted a slight reduction on fungal growth, it proved to be effective in reducing patulin accumulation, in a dose-dependent way. These results were not surprising, as the antitoxigenic properties of phenolic antioxidants with any interference on fungal growth has already been reported (Kim et al., 2008). However, since quercetin proved to be much more stable in acidic conditions (S.M. Sanzani, unpublished data), as those typically present in apple tissues, and considering that the in vitro evaluation of the antifungal activity of a compound is just the first step to test its suitability in preventing the growth and development of a phytopathogenic microorganism, quercetin was further tested in vivo by adding it to wounds (100 $\mu \mathrm{g} /$ wound) of Golden Delicious and Granny Smith apples. The compound not only confirmed the suppressive activity on toxin accumulation, but proved to be effective in controlling blue mould incidence and severity. In particular, the best results were observed on Golden Delicious, the apple cultivar considered more resistant to diseases, and on disease severity control, i.e. practically slowing down disease development. The chance of an application by dipping was investigated; however, results were weaker since the wider surface to be treated was not taken into account.

Considering that, although slightly active on in vitro fungal growth, quercetin was effective in consistently controlling in vivo blue mould, it was hypothesized that quercetin could act by enhancing host natural defence response. A further clue came from a paper by Sanzani et al. (2010) in which quercetin proved to exert its activity even in lack of direct contact with the pathogen, particularly when $P$. expansum was inoculated $24-48 \mathrm{~h}$ after quercetin application. Thus, to try to gain much insight into the mode of action of quercetin, a molecular technique, called Suppression Subtractive Hybridization (SSH), was applied to identify apple genes putatively induced by its application. Results revealed that a substantial number of enzymes or proteins, which have a function in the adaptation process to oxidative or more general stresses, seemed to be up-regulated after quercetin application. In particular, the antifungal activity seemed to be mainly associated to pathogenesis-related proteins family 10, expressed also in response to challenge with Venturia inaequalis, and to PhzC/PhzF proteins. These proteins are tightly linked to structural genes and enzymes from the shikimic acid and tryptophan biosynthetic pathway, known to be involved in the biosynthesis of all the plant phenolic compounds, including phytoalexins and lignin. As a consequence of this response, the fruit should be prepared for a successful defence against pathogens.

Concerning quercetin effect on patulin production, the good results obtained independently from the effect on the fungal growth, suggested that the compound might act directly on toxin biosynthetic pathway, which is mainly associated with fungal secondary metabolism. In a study on the topic Sanzani et al. (2009c) proved that the expression level of selected genes, 
known to code enzymes involved in patulin biosynthesis (i.e. the 6-methylsalicilic acid synthase, the isoepoxydon dehydrogenase, an $\mathrm{ABC}$ transporter and two cytocrome P450 monoxygenases), was determined by quantitative real-time PCR. Results evidenced that quercetin down-regulated the expression of two P450 monooxygenases involved in oxygen activation. These results are consistent with quercetin antioxidant properties and with a similar study in which it is reported that the application of the antioxidant phenolic compound caffeic acid reduced aflatoxin production and down-regulated P450 monooxygenases (Kim et al., 2008). Therefore, the initial hypothesis about a presumed direct activity of quercetin on patulin biosynthetic pathway, particularly at the transcriptional level, seems to be confirmed.

\section{Conclusions}

From this review it appears that some significant progress has been made toward alternative control of postharvest diseases on fruit. Some biofungicides are already on the market in a few countries, and will probably become more widely available as they are registered in more areas. For instance, quercetin might represent an interesting alternative to synthetic fungicides to be applied in the postharvest phase of apples against blue mould and relevant patulin accumulation. Indeed, on the basis of new available information on the mode of action, further studies might lead to the determination of proper conditions to improve their applicability on a commercial scale.

Under field conditions, many alternative control agents have provided limited success, which is often attributed to "uncontrollable" environmental conditions. However, the likelihood of success greatly increases during the postharvest phase due to better environmental control. Moreover, it is often easier to effectively apply alternative control agents while commodities are being processed after harvest.

The success of alternative control greatly depends on influencing the consumer to prefer inner quality to outward appearance. Indeed, alternative control means might represent an important if not essential component of an integrated disease management scheme aimed to reduce economic losses and risks for consumers' health.

\section{References}

Adikaram, N.K.B., Brown, A.E., \& Swinburne, T.R. 1982. Phytoalexin involvement in the latent infection of Capsicum annuum L. fruit by Glomerella cingulata (Stonem.). Physiological Plant Pathology, 21, pp. 161-170, ISSN 0048-4059

Adrian, M., Jeandet, P, Veneau, J., Weston, L.A., \& Bessis, R. 1997. Biological activity of resveratrol, a stilbenic compound from grapevines, against Botrytis cinerea, the causal agent for gray mould. Journal of Chemical Ecology, 23, pp. 1689-1702, ISSN 0098-0331

Afek, U., Aharoni, N., \& Carmeli, S. 1995a. The involvement of marmesin in celery resistance to the pathogens during storage and the effect of temperature on its concentration. Phytopathology, 85, pp. 1033-1103, ISSN 0031949X

Afek, U., Aharoni, N., \& Carmeli, S. 1995b. Increasing celery resistance or pathogens during storage and reducing high-risk psoralen concentration by treatment with GA3. American Society for Horticultural Science, 120, pp. 562-565, ISSN 0003-1062 
Afek, U., Carmeli, S., \& Aharoni, N. 1995c. Columbianetin, a phytoalexin associated with celery resistance to pathogens during storage. Phytochemistry, 39, pp. 1347-1350, ISSN 0031-9422

Afek, U., Orenstein, J., Carmeli, S., Rodovc, V., \& Joseph, M.B. 1999. Umbelliferone, a phytoalexin associated with resistance of immature Marsh grapefruit to Penicillium digitatum. Phytochemistry, 49, pp. 1129-1132, ISSN 0031-9422

Allameh, A., Razzaghi, A.M., Shams, M., Rezaee, M.B., \& Jaimand, K. 2001. Effects of neem leaf extract on production of aflatoxins and activities of fatty acid synthetase, isocitrate dehydrogenase and glutathione S-transferase in Aspergillus parasiticus. Mycopathologia, 154, pp. 79-84, ISSN 0301-486X

Andersen, B., Smedsgaard, J., \& Frisvad, J.C. 2004. Penicillium expansum: consistent production of patulin, chaetoglobosins, and other secondary metabolites in culture and their natural occurrence in fruit products. Journal of Agricultural and Food Chemistry, 52, pp. 2421-2428, ISSN 0021-8561

Arnoldi, A., \& Merlini, L. 1990. Lipophilicity-antifungal relationships for some isoflavonoid phytoalexins. Journal of Agricultural and Food Chemistry, 38, pp. 834-838, ISSN 00218561

Arul, J. 1994. Emerging technologies for the control of postharvest diseases of fresh fruits and vegetables. In: Biological Control of Postharvest Diseases - Theory and Practice. Wilson, C.L., \& Wisniewski, M.E., pp. 1-10, CRC Press, Boca Raton, FL, USA

Báidez, A.G., Gómez, P., Del Río J.A., \& Ortuño A. 2006Antifungal capacity of major phenolic compounds of Olea europaea L. against Phytophthora megasperma Drechsler and Cylindrocarpon destructans (Zinssm.) Scholten. Physiological and Molecular Plant Pathology, 69, 4-6, pp. 224-229, ISSN 0885-5765

Baraldi, E., Mari, M., Chierici, E., Pondrelli, M., Bertolini, P., \& Pratella, G.C. 2003. Studies on thiabendazole resistance of Penicillium expansum of pears: pathogenic fitness and genetic characterization. Plant Pathology, 52, pp. 362-370, ISSN 1365-3059

Barkai-Golan, R., \& Aharoni, Y. 1976. The sensitivity of food spoilage yeasts to acetaldehyde vapors. Journal of Food Science, 41, pp. 717-718, ISSN 1750-3841

Ben-Yehoshua, S., Rodov, V., Kim, J.J., \& Carmeli, S. 1992. Preformed and induced antifungal materials of citrus fruits in relation to the enhancement of decay resistance by heat and ultraviolet treatments. Journal of Agricultural and Food Chemistry, 40, pp. 1217-1221, ISSN 0021-8561

Bock, K.W. 2003. Vertebrate UDP-glucuronosyltransferases: functional and evolutionary aspects. Biochemical Pharmacology, 66, pp. 691-696, ISSN 0006-2952

Brook, P.J. 1977. Glomerella cingulata and bitter rot of apples. New Zealand Journal of Agricultural Research, 20, pp. 547-555, ISSN ISSN 1175-8775

Brown, A.E., \& Swinburne, T.R. 1980. The resistance of immature banana fruits to anthracnose Colletotrichum musae (Berk. \& Curt. Arx). Journal of Phytopathology, 99, pp. 70-80, ISSN 1439-0434

Burse, A., Weingart, H., \& Ullrich, M.S. 2004. The phytoalexin-inducible multidrug efflux pump AcrAB contributes to virulence of fire blight pathogen Erwinia amylovora. Molecular Plant Microbe Interactions, 17, 1, pp. 43-54, ISSN 0894-0282

Celotti, E., Ferrarini, R., Zironi, R., \& Conte, L.S. 1996. Resveratrol content of some wines obtained from dried Valpolicella grapes: Recioto and Amarone. Journal of Chromatography A., 730, 1-2, pp. 47-52, ISSN 0021-9673. 
Céspedes, C.L., Avila, J.G., Martínez, A., Serrato, B., Calderón-Mugica, J.C., \& SalgadoGarciglia, R. 2006. Antifungal and Antibacterial Activities of Mexican Tarragon (Tagetes lucida). Journal of Agricultural and Food Chemistry, 54, 10, pp. 3521-3527, ISSN 0021-8561

Chalutz, E., Devay, J.E., \& Maxie, E.C. 1969. Ethylene induced isocoumarin formation in carrot root tissue. Plant Physiology, 44, pp. 235-241, ISSN 1532-2548

Chalutz, E., \& Droby, S. 1997. Biological control of postharvest disease. In: Plant-microbe interactions and biological control. Boland, G.J., \& Kuykendall, L.D., pp. 157-170, Marcel Dekker Inc., New York, USA

Chen, L., Ingham B.H., \& Ingham, S.C. 2004. Survival of Penicillium expansum and patulin production on stored apples after wash treatments. Journal of Food Science, 69, pp. C669-C675, ISSN 1750-3841

Coxon, D.T., Curtis, R.F., Price, K.R., \& Levett, G. 1973. Abnormal metabolites produced by Daucus carota roots stored under conditions of stress. Phytochemistry, 12, pp. 18811885, ISSN 0031-9422

Coxon, D.T., Pwuce, K.R., Howard, B., Osman, S.F., Kaan, E.B., Zacharius, R.M. 1974 Two new vetispirane derivatives: stress metabolites from potato (Solanum tuberosum) tubers. Tetrahedron Letters, 34, pp. 2921-2924, ISSN 0040-4039

D’hallewin, G., Schirra, M., Pala, M., \& Ben-Yehoshua, S. 2000. Ultraviolet C irradiation at $0.5 \mathrm{kJâm}^{-2}$ reduces decay without causing damage or affecting postharvest quality of Star Ruby grapefruit (C. paradisi Macf.). Journal of Agricultural and Food Chemistry, 48, pp. 4571-4575, ISSN 0021-8561

Deveraj, H., Shanmugasundaram, K.R., \& Shanmugasundaram, E.R.B. 1982. Neurotoxic effect of patulin. Indian journal of experimental biology, 20, pp. 230-231, ISSN:00195189

Dixon, R.A. 2001. Natural products and plant disease resistance. Nature, 411, pp. 843-847, ISSN 0028-0836

Eckert, J.W., \& Ogawa, J.M. 1988. The chemical control of postharvest diseases: deciduous fruits, berries, vegetables and root/tuber crops. Annual Review of Phytopathology, 26, pp. 433-469, ISSN 0066-4286

Edney, K.L. 1978. The infection of apples by Phytophthora syringae. Annals of Applied Biology, 88, pp. 31-36, ISSN 0003-4746

Edney, K.L. 1983. Top fruit. In: Post-Harvest Pathology of Fruits and Vegetables, Dennis, C., pp. 43-71, Academic Press, London, UK

Engstrom, K., Widmark, A.K., Brishammar, S., \& Helmersson, S. 1999. Antifungal activity to Phytophthora infestants of sesquiterpenoids from infected potato tubers. Potato Research, 42, pp. 43-50, ISSN 0014-3065

European Commission, 2006. Commission Regulation (EC) no. 1881/2006 setting maximum levels for certain contaminants in foodstuffs. Official Journal of the European Union, L, 364, pp.5-24, ISSN 1725-2555

Fallik, E. 2010. Hot Water Treatments of Fruits and Vegetables for Postharvest Storage. In: Horticultural Reviews (volume 38), Janick, J., John Wiley \& Sons, Inc., Hoboken, NJ, USA, doi: 10.1002/9780470872376.ch5

FAO Statistical Database (FAOSTAT), 2011. Statistics on agriculture, nutrition, fisheries, forestry, food aid, land use and population. Retrieved from: http://faostat.fao.org/ 
Gonzalez Ureňa A., Orea, J.M., Montero, C., \& Jimenez, J.B. 2003. Improving postharvest resistance in fruits by external application of trans-resveratrol. Journal of Agricultural and Food Chemistry, 51, pp. 82-89, ISSN 0021-8561

Gottstein, D., \& Gross, D. 1992. Phytoalexins of woody plants. Trees, 6, pp. 55-68, ISSN 14322285

Hall, E.G., \& Scott, K.J. 1989. Pome fruit. In: Temperate Fruit, Beattie, BB., McGlasson, W.B., \& Wade, N.L., pp. 7-35, CSIRO Pub., Melbourne, Australia.

Harborne, J.B. 1999. The comparative biochemistry of phytoalexin induction in plants. Biochemical Systematics and Ecology, 27, pp. 335-337, ISSN 0305-1978

Ingham, J.L. 1972 Phytoalexins and other natural products as factors in plant disease resistance. Botanical Review, 38, pp. 343-424, ISSN 0006-8101

Ippolito, A., El Ghaouth, A., Wilson, C.L., \& Wisniewski, M. 2000. Control of postharvest decay of apple fruit by Aureobasidium pullulans and induction of defense responses. Postharvest Biology and Technology, 19, pp. 265-272, ISSN 0925-5214

Ippolito A., Nigro, F., \& Schena, L. 2004. Control of postharvest diseases of fresh fruits and vegetables by preharvest application of antagonistic microorganisms. In: Crop Management and Postharvest Handling of Horticultural Products, Volume 4: Diseases and Disorders of Fruits and Vegetables. Dris, R., Niskanen, R., \& Jain, S.M., pp. 1- 29, Science Publishers, Inc. Enfield, NH, USA

Ishida, T., Naito, E., Mutoh, J., Takeda, S., Ishii, Y., \& Yamada, H. 2005. The plant flavonoid, quercetin, reduces some forms of dioxin toxicity by mechanisms distinct from aryl hydrocarbon receptor activation, heat shock protein induction and quenching oxidative stress. Journal of Health Science, 51, pp. 410-417, ISSN 1916-9744

Iwashina, T. 2003. Flavonoid Function and Activity to Plants and Other Organisms. Biological Sciences in Space, 17, pp. 24-44, ISSN 1349-967X

Janick, J., Cummings, J.N., \& Hemmat, M. 1996. Apples. In: Fruit Breed, vol I: Tree and tropical Fruit, Janick, J., \& Moore, J.M., Wiley \& Sons Inc, Hoboken, NJ, USA, ISBN 978-0471-31014-3

Janisiewicz, W., Yourman, L., Roitman, J., \& Mahoney, N. 1991. Postharvest control of blue mold and gray mold of apples and pears by dip treatment with pyrrolnitrin, a metabolite of Pseudomonas cepacia. Plant Disease, 75, pp. 490-494, ISSN 0191-2917

Jeandet, P., Bessis, R., Sbaghi, M., \& Meunier, P. 1995. Production of the phytoalexin resveratrol by grapes as a response to Botrytis attack under natural conditions. Journal of Phytopathology, 143, pp. 135-139, ISSN 1439-0434

Juniper, B.E., \& Mabberley, D.J. 2006. The Story of the Apple. Timber Press, OR, USA, ISBN 088192-784-8

Katsui, N., Matsunaga, A., \& Masamune, T. 1974. The structure of lubimin and oxylubimin, antifungal metabolites from diseased potato tubers. Tetrahedron Letters, 51/52, pp. 4483-4486, ISSN 0040-4039

Katsui, N., Matsunaga, A., Imaizumi, K., Masamune, T., \& Tomiyama, K. 1972. Structure and synthesis of rishitinol, a new sesquiterpene alcohol from diseased potato tubers. Bulletin of the Chemical Society of Japan, 45, 2871-2877, ISSN 1348-0634

Kim, J.J., Ben-Yehoshua, S., Shapiro, B., Henis, Y., \& Carmeli, S. 1991. Accumulation of scoparone in heat-treated lemon fruit inoculated with Penicillium digitatum Sacc. Plant Physiology, 97, pp. 880-885, ISSN 1532-2548 
Kim, J.H., Yu, J., Mahoney, N., Chan, K.L., Molyneux, R.J., Varga, J., Bhatnagar, D., Cleveland, T.E., Nierman, W.C., \& Campbell, B.C. 2008. Elucidation of the functional genomics of antioxidant-based inhibition of aflatoxin biosynthesis. International Journal of Food Microbiology, 122, pp. 49-60, ISSN 0168-1605

Kloepper, J.W., Tuzun, S., \& Kuc, J.A., 1992. Proposed definitions related to induced disease resistance. Biocontrol Science and Technology, 2, pp. 349-351, ISSN 1360-0478

Kuc, J. 1976. Phytoalexins. In: Encyclopedia of Plant Physiology, New Sen Vol. 4, Physiological Plant Pathology. Heitefuss, R., \& Williams, P.H., pp. 632-652, Springer-Verlag Berlin Heidelberg, New York, USA

Kuc, J. 2000. Development and future direction of induced systemic acquired resistance in plants. Crop Protection, 19, pp. 859-861, ISSN 0261-2194

Langcake, P. 1981. Disease resistance of Vitis spp. and the production of the stress metabolites resveratrol, $\varepsilon$-viniferin, a-viniferin and pterostilbene. Physiological and Molecular Plant Pathology, 18, pp. 213-226, ISSN 0885-5765

Lovett, J., Thompson, R.G., \& Boutin B.K. 1975. Patulin production in apples stored in a controlled atmosphere. Journal of the Association of Official Analytical Chemists, 58, pp. 912-914, ISSN 0004-5756

Luckey, T.D. 1980. Hormesis with Ionizing Radiation. CRC Press, Boca Raton, FL, USA

Mahalingam, R., Gomez-Buitrago, A.M., Eckardt, N., Shah, N., Guevara-Garcia, A., Day, P., Raina, R., \& Fedoroff, N.V. 2003, Characterizing the stress/defense transcriptome of Arabidopsis. Genome Biology, 4, pp. R20, ISSN 1465-6914

Mari, M., Leoni, O., Iori, R., \& Cembali, T. 2002. Antifungal vapour-phase activity of allyisothiocyanate against Penicillium expansum on pears. Plant Pathology, 51, 231-236, ISSN 1365-3059

Minamikawa, T., Akazawa, T., \& Utitani, I. 1963. Analytical study of umbelliferone and scopoletin synthesis in sweet potato roots infected by Ceratocystis fimbriata. Plant Physiology, 38, pp. 493-497, ISSN 1532-2548

Morales, H., Sanchis, V., Usall, J., Ramos, A.J., \& Marin, S. 2008. Effect of biocontrol agents Candida sake and Pantoea agglomerans on Penicillium expansum growth and patulin accumulation in apples. International Journal of Food Microbiology, 122, 1-2, pp. 61-67, ISSN 0168-1605

Mossini, S.A.G., De Oliveira K.P., \& Kemmelmeier, K. 2004. Inhibition of patulin production by Penicillium expansum cultured with neem (Azadirachta indica) leaf extracts. Journal of Basic Microbiology, 44, pp. 106-113, ISSN 1521-4028

Muller, K., \& Borger, H. 1940. Experimentelle Untersuchungen uber die Phytophthora Resistenz der Kartoffel. Arb Biol Reichsanst Land Forstwirtsch, 23, pp. 189-231, ISSN 0077-961

Murphy, P.A., Hendrich, S., Landgren, C., \& Bryant C.M. 2006. Food Mycotoxins: An Update. Journal of Food Science 71 (5), pp. R51-R65, ISSN 0022-1147

Nijveldt, R.J., van Nood, E., van Hoorn, D.E.C., Boelens, P.G., van Norren, K., \& van Leeuwen P.A.M. 2001. Flavonoids: a review of probable mechanisms of action and potential applications. American Journal of Clinical Nutrition, 74, pp.418-425, ISSN 1938-3207

Okull, D.O., \& LaBorde, L.F. 2004. Activity of electrolyzed oxidizing water against Penicillium expansum in suspension and on wounded apples Journal of Food Science, 69, 23-27, ISSN 0022-1147 
Okull, D.O., Demirci, A., Rosenberger, D., LaBorde, L.F. 2006. Susceptibility of Penicillium expansum spores to sodium hypochlorite, electrolyzed oxidizing water, and chlorine dioxide solutions modified with nonionic surfactants. Journal of Food Protection, 69, 8, pp. 1944-1948, ISSN 0362-028X

Palou, L., Smilanick, J.L., \& Droby, S. 2008. Alternatives to conventional fungicides for the control of citrus postharvest green and blue moulds. Stewart Postharvest Review, 4, 2, pp. 1-16, ISSN 1745-9656

Paster, N., Huppert, D., \& Barkai-Golan R. 1995. Production of patulin by different strains of Penicillium expansum in pear and apple cultivars stored at different temperatures and modified atmospheres. Food Additives and Contaminants, 12, 51-58, ISSN 1464-5122.

Paucod, J.C., Krivobok, S., \& Vidal, D. 1990. Immunotoxicity testing of mycotoxins T-2 and patulin on Balb/c mice. Acta Microbiologica et Immunologica Hungarica, 37, 143-146, ISSN 1588-2640.

Phipps, J.B., Robertson, K.R., Smith, P.G., \& Rohrer, J.R. 1990. A checklist of the subfamily Maloideae (Rosaceae). Canadian Journal of Botany, 68, pp. 2209-2269, ISSN 1480-3305

Rodov, V., Ben-Yehoshua, S., Kim, J.J., Shapiro, B., \& Ittah, Y. 1992. Ultraviolet illumination induces scoparone production in kumquat and orange fruit and improves decay resistance. Journal of the American Society for Horticultural Science, 117, pp. 788-792, ISSN 0003-1062

Ryals, J.A., Neuenschwander, U.H., Willits, M.G., Molina, A., Steiner H.Y., \& Hunt, M.D.. 1996. Systemic acquired resistance. The Plant Cell, 8, pp. 1809-1819, ISSN 1532-298X

Ryu, D., \& Holt, D.L. 1993. Growth inhibition of Penicillium expansum by several commonly used food ingredients. Journal of Food Protection, 56, pp. 862-867, ISSN 0362-028X

Sanzani, S.M., Nigro, F., Mari, M., \& Ippolito, A., 2009a. Innovations in the control of postharvest diseases of fresh fruit and vegetables (short paper). Arab Journal of Plant Protection. Arab Journal of Plant Protection, 27, 2, pp. 240-244, ISSN 0255-983X

Sanzani, S.M., De Girolamo, A., Schena, L., Solfrizzo, M., Ippolito, A., \&Visconti, A. 2009b. Control of Penicillium expansum and patulin accumulation on apples by quercetin and umbelliferone. European Food Research and Technology, 228(3), pp. 381-389, ISSN 1438-2385

Sanzani, S.M., Schena, L., De Girolamo, A., Nigro, F., \& Ippolito, A. 2009c. Effect of quercetin and umbelliferone on the transcript level of Penicillium expansum genes involved in patulin biosynthesis. European Journal of Plant Pathology, 125, 2, pp. 223-233, ISSN 1573-8469

Sanzani, S.M., Schena, L., De Girolamo, A., Ippolito, A., \& González-Candelas, L., 2010. Characterization of genes associated to induced resistance against Penicillium expansum in apple fruit treated with quercetin. Postharvest Biology and Technology, 56, pp. 1-11, 0925-5214, ISSN 0925-5214

Schena, L., Nigro, F., \& Ippolito, A. 2007. Natural antimicrobials to improve storage and shelf-life of fresh fruit, vegetables and cut flowers. In: Microbial Biotechnology in Horticulture, Vol. 2., Ray, R.C., \& Ward, O.P., pp. 259-303, Oxford \& IBH Publishing Co., New Delhi, India, ISBN 1578084172

Sharma, R.R., Singh, D., Singh, R., 2009. Biological control of postharvest diseases of fruits and vegetables by microbial antagonists: A review. Biological Control, 50, 3, pp. 205221, ISSN 1049-9644 
Sholberg, P., Haag, P., Hocking, R., \& Bedford, K. 2000. The use of vinegar vapor to reduce postharvest decay of harvested fruit. Horticultural Science, 35, pp. 898-903, ISSN 0862-867X.

Smith, C.J. 1996. Accumulation of phytoalexins: defence mechanism and stimulus response system. New phytologist, 132, pp. 1-45, ISSN 0028-646X

Snowdon, A.L. 1990. Post-Harvest Diseases and Disorders of Fruits and Vegetables, Vol. 1. General Introduction and Fruits, CRC Press, Inc., Boca Raton, FL, USA.

Sommer, N.F., Buchanan, J.R., \& Fortlage, R.J. 1974. Production of patulin by Penicillium expansum. Applied and Environmental Microbiology, 28, pp. 589-593, ISSN 1098-5336.

Spadaro, D., Garibaldi, A., \& Gullino, M.L. 2004. Control of Penicillium expansum and Botrytis cinerea on apple combining a biocontrol agent with hot water dipping and acibenzolar-S-methyl, baking soda, or ethanol application. Postharvest Biology and Technology, 33, 2, pp. 141-151, ISSN 0925-5214

Spotts, R.A., Cervantes, L.A., \& Mielke, E.A. 1999. Variability in postharvest decay among apple cultivars. Plant Disease, 83, pp. 1051-1054, ISSN 0191-2917

Sticher, L., Mauch-Mani, B., \& Métraux J.P. 1997. Systemic acquired resistance. Annual Review of Phytopathology, 35, pp. 235-270, ISSN 0066-4286

Stoessl, A., Unwin, C.H., \& Ward, E.W.B. 1972. Post-infectional inhibitor from plants. I. Capsidiol, an antifungal compound from Capsicum frutescens. Phytopathology Z., 74, pp. 141-152, ISSN 0031-9481

Sutton, B.C. 1996. A century of mycology. British Mycological Society Century Symposium. Ed. Cambridge University Press, UK, ISBN 9780521050197

Swinburne, T.R. 1973. The resistance of immature Bramley's seedling apples to rotting by Nectria galligena Bres. In: Fungal Pathogenicity and the Plant's Response. Byrde, R.J.W., \& Cutting, C.V., pp. 365-382, Academic Press, London, UK, ISBN 0121488500

Swinburne, T.R. 1975. Microbial proteases as elicitors of benzoic acid accumulation in apples. Phytopathology Z., 82, pp.152-162, ISSN 0031-9481

Swinburne, T.R. 1983. Quiescent infections in postharvest diseases. In: Postharvest Pathology of Fruits and Vegetables, Dennis, C., pp. 1-21, Academic Press, London, UK

Tomiyama, K., Sakuma, T., Ishizaka, N., Katsui, N., Takasugi, M., \& Masamune, T. 1968. A new antifungal substance isolated from resistant potato tuber tissue infected by pathogens. Phytopathology, 58, pp. 115-116, ISSN 0031-949X

Walker, T.S., Bais, H.P., Halligan, K.M., Stermitz, F.R., \& Vivanco, J.M. 2003. Metabolic Profiling of Root Exudates of Arabidopsis. Journal of Agricultural and Food Chemistry, 51, pp. 2548-2554, ISSN 0021-8561

Zhang, H., Wang, L., Ma, L., Dong, Y., Jiang, S., Xu, B., \& Zheng, X., 2009. Biocontrol of major postharvest pathogens on apple using Rhodotorula glutinis and its effects on postharvest quality parameters. Biological Control, 48, 1, pp. 79-83, ISSN 1049-9644 


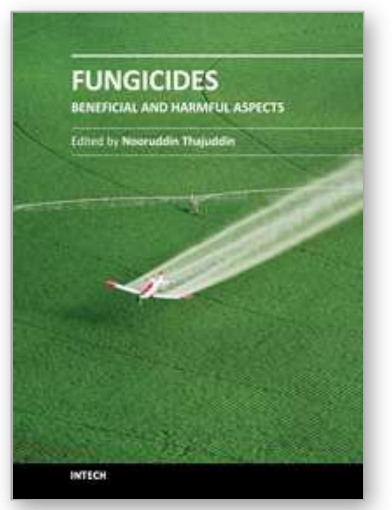

\author{
Fungicides - Beneficial and Harmful Aspects \\ Edited by Dr. Nooruddin Thajuddin
}

ISBN 978-953-307-451-1

Hard cover, 254 pages

Publisher InTech

Published online 16, December, 2011

Published in print edition December, 2011

Fungicides are a class of pesticides used for killing or inhibiting the growth of fungus. They are extensively used in pharmaceutical industry, agriculture, in protection of seed during storage and in preventing the growth of fungi that produce toxins. Hence, fungicides production is constantly increasing as a result of their great importance to agriculture. Some fungicides affect humans and beneficial microorganisms including insects, birds and fish thus public concern about their effects is increasing day by day. In order to enrich the knowledge on beneficial and adverse effects of fungicides this book encompasses various aspects of the fungicides including fungicide resistance, mode of action, management fungal pathogens and defense mechanisms, ill effects of fungicides interfering the endocrine system, combined application of various fungicides and the need of GRAS (generally recognized as safe) fungicides. This volume will be useful source of information on fungicides for post graduate students, researchers, agriculturists, environmentalists and decision makers.

\title{
How to reference
}

In order to correctly reference this scholarly work, feel free to copy and paste the following:

Simona Marianna Sanzani and Antonio Ippolito (2011). State of the Art and Future Prospects of Alternative Control Means Against Postharvest Blue Mould of Apple: Exploiting the Induction of Resistance, Fungicides Beneficial and Harmful Aspects, Dr. Nooruddin Thajuddin (Ed.), ISBN: 978-953-307-451-1, InTech, Available from: http://www.intechopen.com/books/fungicides-beneficial-and-harmful-aspects/state-of-the-art-and-futureprospects-of-alternative-control-means-against-postharvest-blue-mould-of

\section{INTECH}

open science | open minds

\section{InTech Europe}

University Campus STeP Ri

Slavka Krautzeka 83/A

51000 Rijeka, Croatia

Phone: +385 (51) 770447

Fax: +385 (51) 686166

www.intechopen.com

\section{InTech China}

Unit 405, Office Block, Hotel Equatorial Shanghai

No.65, Yan An Road (West), Shanghai, 200040, China

中国上海市延安西路65号上海国际贵都大饭店办公楼 405 单元

Phone: +86-21-62489820

Fax: $+86-21-62489821$ 
(C) 2011 The Author(s). Licensee IntechOpen. This is an open access article distributed under the terms of the Creative Commons Attribution 3.0 License, which permits unrestricted use, distribution, and reproduction in any medium, provided the original work is properly cited. 